Butler University

From the SelectedWorks of Chad M. Bauman

2017

Pentecostals and Interreligious Conflict in India: Proselytization, Marginalization, and AntiChristian Violence

Chad M Bauman

Available at: https://works.bepress.com/chad_bauman/73/ 
[PS 16.1 (2017) 8-34]

PentecoStudies (print) ISSN 2041-3599

https://doi.org/10.1558/ptcs.31724

PentecoStudies (online) ISSN 1871-7691

\title{
Pentecostals and Interreligious Conflict in India: Proselytization, Marginalization And Anti-Christian VIOLENCE
}

\author{
Chad M. Bauman ${ }^{1}$ \\ Centre for Pentecostal and Charismatic Studies \\ Butler University \\ Indianapolis \\ USA \\ cbauman@butler.edu
}

\begin{abstract}
Anti-Christian violence in India has increased dramatically since the late 1990s, and there are now, on average, several hundred attacks on Christians every year. In this violence, Pentecostals are disproportionately targeted. This article begins by providing the historical and political context for anti-Christian violence, and then seeks to account for the disproportionate targeting of Pentecostals. While there are certain obvious factors, such as the more assertive evangelizing of Pentecostals (and other Evangelicals) vis-à-vis mainstream Christian groups, the article explores and highlights several less obvious factors, and in particular the peculiar social, theological, ecclesiastical and liturgical aspects of Pentecostalism that make this form of Christianity particularly objectionable to Hindu nationalists, as well - importantly - as to many mainstream and upper-caste/upper-class Indian Christians.
\end{abstract}

Keywords: violence, anti-Christian, Hindutva, Hindu-Christian, Pentecostal, Evangelism, India, Hinduism, Christianity.

Since the late 1990s, there has been a sharp increase in the frequency of incidents of anti-Christian violence in India, and since the beginning of the new millennium, there are, by the best estimates, around 250 to 350 incidents of anti-Christian violence annually. Moreover, many believe

1. Chad M. Bauman is professor of religion and chair of the Department of Philosophy, Religion, and Classics at Butler University. He specializes in the interaction of Hindus and Christians in India, both historically and in the contemporary period. His most recent book is Pentecostals, Proselytization, and anti-Christian Violence in Contemporary India (Oxford University Press, 2008). 
the frequency has even increased since the 2014 electoral victory of the Bharatiya Janata Party (BJP), which espouses the Hindu nationalist ideology of Hindutva, or "Hindu-ness", the idea that the special genius and future success of the Indian nation are dependent on its Hindu cultural and religious identity, and on the people who can call India both "Fatherland" (Pitribhu) and "Holy Land" (Punyabhu; see Savarkar, 1928: 116) This is an idea that, for obvious reasons, marginalizes and threatens minority religions in India, particularly those, like Islam and Christianity, that have been discursively constructed by their opponents, since the colonial period, as "foreign" religions (despite, in the case of Christianity, having had a presence in India for over a millennium and a half).

There are two primary forms of anti-Christian violence: (1) riot violence and (2) what I call "everyday" acts of violence. The first form, riot violence, is incredibly rare, but is more dramatic, and has tended, in the case of Christians, to be far more deadly. The most deadly and best known of these riots took place in the Kandhamal region of Odisha, India, in 2007-8. During this violence, dozens of Christians (and even some Hindus) were killed. Hundreds more were physically or sexually assaulted and driven from their homes (many of which were significantly damaged or destroyed). Most of these victims were again Christians, though one entire Hindu neighbourhood also burned down. At the height of the violence, which came in waves over several months, around five thousand Kandhamalis were in refugee camps. Many never returned, and the religious demographics of Kandhamal have been permanently and irreversibly altered.

Riot violence such as this receives widespread media attention, both in India and abroad. But it is not the focus of this article. Riot violence tends to be more indiscriminate, and often involves an influx of criminal out-of-towners who know little about the community they invade. For this reason, the vandalism and violence of anti-Christian riots is somewhat more ecumenical than that which occurs in the "everyday" acts of violence, and may even more seriously affect mainstream Protestant, Catholic and Orthodox Christians, whose more established and substantial physical presence makes them more easily identifiable, and more easily targeted.

The attention that these very rare riots receive perhaps obscures the fact that anti-Christian violence is not an aberration in contemporary India, but is rather a consistent and widespread problem. There are, as already indicated, around 250 to 350 acts of anti-Christian violence a year in India. These incidents are diffuse, and generally involve very local 
actors targeting one or a small number of carefully chosen victims in response, these actors say - though we have reason to be sceptical of their claims ${ }^{2}$ - to some specific provocation (e.g. aggressive or hypercritical proselytization, a high-profile conversion, the establishment of a church, signs of increasing Christian wealth, noisy or raucous worship). I call these incidents "everyday" not to downplay their severity, but rather for two reasons: first, they are "everyday" in the literal sense of occurring almost every day; second, they are "everyday" in the sense of going largely unnoticed, and being considered, by many Indians, rather unremarkable.

It is in these "everyday" acts of violence that Pentecostals (and Evangelicals more generally) are disproportionately targeted. In 2007, for example, according to my own data, mainstream Protestant, Catholic and Orthodox groups were targeted in only 13 per cent of anti-Christian incidents of violence, despite comprising, according to the best statistics (Barrett, Kurian and Johnson, 2001: 360), at least 50 per cent of India's Christians. ${ }^{3}$ India's Evangelicals and Pentecostals (in the broadest sense) then, who together constitute fewer than 50 per cent of India's Christians, account for fully 87 per cent of the targets of "everyday" anti-Christian violence (Bauman and Leech, 2011).

That little caveat - "Pentecostals (in the broadest sense)" - requires a definitional aside. In this article, I use "Pentecostal" to refer to nearly the full range of what Johnson and Ross, in the Atlas of Global Christianity, call "renewalist" Christianity. "Renewalist" Christianity, for Johnson and Ross (2009: 102-3), includes classical Pentecostal denominations, neo-Pentecostals/neo-charismatics, Roman Catholic charismatics, and denominationally independent Protestants who are pentecostalized in theology and worship, but not formally identified with any classical Pentecostal denomination. The groups included in this broad category roughly correspond with those that are disproportionally targeted in

2. Those who commit or justify violence against Christians often frame it as a response to "provocative" Christian activities. But one must be skeptical of such justifications, both because violence is not always rational, and because such justifications are sometimes deployed to obscure other motivations, like anti-dalit prejudice, the desire to create fear of minorities for political gain, or the desire to disadvantage an economic competitor.

3. In 2008, the proportion of attacks on Catholics (14\%) and total mainstream Protestant, Catholic and Orthodox (21\%) rose significantly, but this reflects the large number of attacks in that year that took place in the context of the Odisha riots (in which, as I've argued, specific targeting declined as mobs in unfamiliar territory targeted clearly recognizable Christian institutions, of which the majority belonged to the older, mainstream Christian denominations). 
anti-Christian violence, with the exception of Roman Catholic charismatics. Catholic charismatics in India tend not to be as regularly targeted as the others just listed, presumably both because they benefit from Roman Catholic denominational strength and security (more on that later), and because they are, relative to the other groups listed here, somewhat less evangelistic. It is to these groups, then - what Johnson and Ross call "Renewalists", minus the Roman Catholic charismatics that I refer when I say that "Pentecostals" are disproportionately targeted in anti-Christian violence.

As an addendum to "Pentecostals", on the list of those most targeted by anti-Christian violence, I usually add what I call "pentecostalized Evangelicals". Scholars have often, with varying degrees of selfconsciousness, conceived of Evangelicalism as genus and Pentecostalism as species, and/or to define Pentecostalism heuristically as "Evangelicalism + tongues". But these categorizations simply don't work in India. I don't have the space in this article to explore the matter fully, but it is abundantly evident that there are many tongues-speaking, self-identified nonPentecostal Evangelicals in India, as well as many Pentecostals who never speak in tongues (privately or collectively). It is also clear that Pentecostal theologies, worship styles and therapeutic practices profligately transgress Indian denominational lines as they spread from home to home, from leader to leader, from music kiosk to music kiosk, and from worship team to worship team, emanating, almost ubiquitously, from open windows, loudspeakers, stereos, radios and televisions (Bergunder, 2008: 221). For this reason it may be useful to abandon the genus/species metaphor, and rather to think of both Evangelicalism and Pentecostalism as species of Christianity that have, in their interaction, produced novel, surviving hybrid species and a hybrid swarm of inter-breeding, backcrossing, intra-specific hybrids, like the hybrid Lonicera fly (that does the same). The term, "pentecostalized Evangelicals", then, is my attempt to honour the complexity of the Indian Christian situation, and to signal that global Pentecostalism's very defiance of definitions may be among the very few things that consistently define it.

In what follows then, I seek to account for the disproportionate targeting of Pentecostals in India's anti-Christian violence. The article begins with an exposition on the rise of Hindutva. Because many Hindus live and desire to live in harmony with adherents of other faiths, the rise of Hindutva helps explain why there is violence against India's religious minorities in the first place (and not just minorities, since differently Hindu and secular Indians are also, at times, the targets of Hindu 
nationalist critique and even violence). Moreover, the particularities of Hindutva's rise help account not only for why minority religions might be targeted by Hindu nationalists, but also for why Pentecostals might be disproportionately targeted in the violence that affects contemporary Indian Christians.

In the second section, then, the article turns its gaze towards Pentecostals themselves, and towards the peculiar social, theological, ecclesiastical and liturgical aspects of Pentecostalism that make it particularly objectionable to those inspired by the ideology of Hindutva (and also, importantly, to many mainstream and upper-caste/upper-class Indian Christians). The point, in the end, is to show how the interaction of diverse social factors and agents both within and between Hindu and Christian (and other) communities conspire to create a context conducive to the disproportionate targeting of Pentecostals.

\section{Hindus, Christians and the Rise of Hindutva}

The construction of Christianity by its Hindu nationalist critics as a problematic "foreign" religion, and of Pentecostalism as a particularly provocative form of that religion, is enabled by the peculiarities of Christian history in India, while being motivated and shaped by the contemporary political agenda of those same Hindu nationalists. India's Christians enjoyed relatively cordial relations with adherents of other religions in India from their establishment, in the early centuries of the first millennium, until the commencement of European colonization beginning in the late fifteenth century. These relations were aided both by the high social status of the earliest St Thomas (or "Syrian") Christians, and by the fact that their religious rituals and practices were similar to, and somewhat integrated with, those of their neighbours. For example, while different religious communities had their own particularities and distinctiveness, adherents of those religions often shared in common, or even interacted with one another in the context of worship and petition at the shrines of powerful, miracle-working saints, gods and goddesses. Moreover, far from being excluded from or avoiding the religious practices of others, St. Thomas Christians in this era often competed for honours at temple feasts sponsored by the dominant Hindu community, and were granted prestigious roles as a high-status community (Bayly, 1989: $8,27,69-74,347-8){ }^{4}$

4. The use of the term "Hindu" is an anachronism in this context, particularly to the extent that it implies beliefs and practices like those of contemporary India and to the 
Speaking in very general terms, European colonization had three significant, lasting and deleterious effects with regard to Hindu-Christian relations. The first, and most obvious, was related to the relationship of Christianity and colonization. Practices varied considerably, and European colonial support for Christian evangelizing was far more uneven than Christianity's critics usually suggest. Nevertheless, missionaries accompanied the early Portuguese Catholic explorers, and were active in the colonies they established. British colonial figures were somewhat more hesitant, at first, to allow Christian missionaries to trouble the religious waters in areas they sought to control, but under the effects of the Evangelical Revival, many became strong supporters of Christian missionary efforts after the 1820 s. Because of this relationship of religion and empire, Christianity came to be linked in the minds of some Indians (perhaps not immediately, but certainly by the nineteenth century), with foreign power, political intrusion, social meddling, and the excesses of imperial rule (including, under the Portuguese, the Inquisition ${ }^{5}$ ). The second effect was that through contact with European missionaries, Indian Christianity was progressively Europeanized, leading to its dis-integration from the local religious milieu, and contributing to the perception that it was a "foreign" religion. ${ }^{6}$ Third, European missionaries' increasing targeting of India's lowest castes and tribes (both because their greater likelihood to convert and because of the fact that they themselves at times initiated and requested contact with missionaries) left Christianity vulnerable to the perception that it was a low-caste religion, and to all of the caste-based prejudice that perception mobilized (Bayly, 1989: 13, 281-4, 92-3, 300-302; Subramanian, 2009: 73-5).

extent that it implies a modern understanding of religious traditions as discrete and mutually exclusive. I use it, nonetheless, merely to simplify things.

5. While the Goan Inquisition primarily targeted apostate Christians, or Christian converts believed to have lapsed into practice of their former faiths, it also enacted and prosecuted those accused of transgressing a variety of laws disprivileging Hindus and restricting Hindu worship and practice (not to mention the fact that the laws themselves encouraged conversion through social coercion).

6. This Europeanization happened both through the agency of convert communities and the intentional actions of Europeans, such as in the Synod of Diamper in 1599, during which St. Thomas Christian groups uniting with the Roman Catholic Church were commanded to abandon certain practices deemed "Hindu" (e.g. on marriage, birth and inter-caste interactions), and to cease attending Hindu festivals they had previously regularly attended. 
Other factors compounded these. For example, late-nineteenthcentury British policies which conceived of India as a nation of religious communities (communities which it began to enumerate in decennial censuses) allocated political power according to community demographics, and further politicized religious numbers such that conversion to minority religions, and particularly the mass movements of conversion to Christianity in the late nineteenth and early twentieth centuries, would be perceived not only as a religious loss by Hindus, but also as a political threat to Hindu political power (Freitag, 1989: 16-19, 57-78; Kidambi, 2007: 159).

Because of these and other factors, when the Indian independence movement began to build steam in the late nineteenth and early twentieth centuries, it was tinctured with a Hindu sensibility and an anti-minority animus directed primarily at Muslims and Christians. The anti-Muslim proclivities were partially (though obviously not fully) responsible for the Partition of Pakistan and India. The anti-Christian inclination manifested itself primarily in the rhetorical Hindu nationalist critique of Christianity as a foreign religion bent on world domination through the conversion of all people by any means necessary, including the unscrupulous use of "Western" political power and wealth.

In 1923, V. D. Savarkar (1883-1966) popularized the term and ideal of "Hindutva" when he published a tract by that name. Inspired by his views, K. B. Hedgewar (1889-1940) founded the Rashtriya Swayamsevak Sangh (RSS) in 1925, which he hoped, by combining instruction, physical exercise and military-style drilling, would infuse "new physical strength into the majority community" (Jaffrelot, 1996: 16). The RSS spawned a whole host of related organizations, including eventually the BJP (whose current Prime Minister, Narendra Modi, was an active member of the RSS). Some of these organizations, like the Akhil Bharatiya Vanvasi Kalyan Ashram (founded in 1952) and the Vishwa Hindu Parishad (founded in 1964) were formed explicitly to counter the influence of Christian missionaries (Sarkar, 1999: 1697; Zavos, 2001: 84). All of these organizations understand themselves as part of the Sangh Parivar, the "family of the Sangh" (that is, the RSS). Gandhi, whose Hindu identity was apparent, and who drew frequently upon Hindus ideas and symbols in the articulation of his political positions, still possessed a concept of the nation that was more inclusive than, and often at odds with, that of those associated with the Sangh and its precursors. Nevertheless, even Gandhi frequently accused Indian Christians of being denationalized, and decried as exploitative missionaries' targeting of lower-caste and tribal peoples, 
and considered the attempt to convert others to one's faith uncouth at best, and a sure sign of debased and unenlightened religion (Kim, 2003: 33; Harper, 2000: 292-345).

As India became an independent country in 1947, its leaders debated, but ultimately rejected, a national anti-conversion law. But many Hindus sympathetic to Sangh ideology remained concerned about the growth and power of India's Christians, or at least feigned concern to help unify Hindus for political gain by pitting them against a commonly constructed enemy. Among the rhetorical devices that enabled this construction was the regular claim, made by Gandhi and increasingly popular after independence, that Christianity in India grew through conversions by "force, fraud and allurement". The rhetorical construction of Christianity as a predatory, foreign religion has been somewhat influential even beyond the inner core of Hindutva ideologues, in part because of the notion, which is quite common among contemporary Hindus, that proselytization is a debased practice unbecoming of the highest, purest forms of religion. (Of course the prevalence of this notion is also partially a product of Hindu nationalist discourse.)

Nationalism in India therefore emerged in the context of what could be usefully construed by Hindu nationalists as colonization by a foreign, Christian nation, and was because of this forever inflected with certain nativist Hindu impulses that were further entrenched during the bisection of British India into Hindu-dominated India and Muslim-dominated Pakistan, with all of the bloodletting and - afterwards - national anxieties that bisection provoked. At the same time, Christianity came to be perceived as a "foreign" religion, and Indian Christians came to be suspected of foreign loyalties and accused of becoming individually denationalized while encouraging the denationalization of others.

These suspicions and accusations were amplified, beginning in the late 1990s, by several highly publicized Christian evangelical efforts (e.g. the AD 2000 and Beyond movement, and the Joshua Project) and the increasingly tangible effects, in the same decade, of globalization in India (which were perceived by Hindu traditionalists as an attack on "traditional Hindu" values). The reason globalization amplified these suspicions and accusations was that Indian Christians, with their frequent establishment of economic cooperatives, their penchant for humanrights talk, their development work among lower-caste and tribal peoples (which threatened to invert traditional hierarchies), their admiration for English fluency, and their ostensibly greater access to foreign capitalist wealth and power, were perceived by many to be the chief proponents, 
purveyors and beneficiaries of globalization's "Western" and "modern" values (Bauman, 2013). ${ }^{7}$

Similarly, it is no surprise that in the context of colonization by a foreign, "Christian" nation that politicized religious demographics, India's Hindu nationalists should consider the possibility of increasing Christian numbers a threat. From a nativist perspective, rising Christian numbers not only represent an increased threat to "traditional Hindu" religion and culture, but also represent a degradation of Hindu political power. And if that weren't enough to provoke concern, there is also, of course, a certain resentment that stems from a particular reading of Indian history that emphasizes the European exploitation of colonial power to further Christianity (by force, occasionally, and more regularly by providing implicit and explicit incentives to India's Christians); the actions of some small number of contemporary evangelists who continue to encourage conversion through implicit and explicit offers of money, healthcare, jobs and education; and the suspicion that even if that weren't true, the aphrodisiacal nature of "Western" culture and its dominant religion, Christianity, has been made so powerful and omnipresent by globalization that all converts could be suspected of having converted through "allurement".

This is particularly true given the vast sums of money that are known to flow from foreign sources into India for the support of Christian relief and missionary work. According to my analysis of data from India's Foreign Contribution (Regulation) Act (Bauman, 2015: ch. 5), nearly one billion US dollars enters India annually for these purposes. If we limit our gaze, for the moment, just to US American Protestant mission organizations (which collectively spend around six billion dollars annually on missions worldwide, and are by far the most involved and influential in worldwide missions) we can discern several trends in the use of missionary money that favour the greater pentecostalization of India, and the increased assertiveness of evangelism there. Two of these trends are most important. The first is a significant withdrawal from directly evangelistic

7. While based in part on reality, this perception has also been intentionally curated by Hindu nationalists to exploit the anxieties of groups (usually lower-class) in direct economic competition with Christians who feel they are falling behind their Christian neighbors because of these factors, or who feel their traditional privileges and advantages are being eroded by the forces of modernization and Westernization. It must be noted, however, that many middle- and upper-class Hindus welcome these social changes, and get along rather well with the middle- and upper-class Christians who do as well. 
work on the part of mainstream Protestant organizations over the last half century, which leaves the work of evangelism and church growth primarily to more evangelistically assertive Evangelicals and Pentecostals. The second is Protestant mission organizations' increased support for "native" missionaries, both for ideological reasons and for reasons of financial and logistical expediency (because native missionaries are paid less, require far less training, immediately understand how to communicate in culturally appropriate and persuasive ways, and have fewer issues with access, visa restrictions, etc.).

The reason this shift towards native missionaries favours the greater pentecostalization of Indian Christianity is that Indian Evangelicals are far more pentecostalized than their American counterparts, and far less concerned about the theological distinctions and boundaries between Evangelicalism and Pentecostalism. They are, moreover, far more attuned personally, and for strategic reasons, to the Indian popular religious appreciation of and demand for ecstatic religious experiences and supernatural physical and spiritual healing. The shift towards native missionaries favours more aggressive forms of evangelism because the wealthy foreign patrons of native missionaries expect return on investment, demanding - far more than was the case with foreign missionaries - that those they support should justify their salaries through more, and more rapid "production" of converts, and thereby also encouraging the unscrupulous among them to exaggerate their evangelistic gains or utilize shady evangelistic methods to achieve them more rapidly. To the extent, then, that Pentecostals are disproportionately targeted in antiChristian violence, and that one factor in that disproportionate targeting is their more assertive evangelism and willingness to demonize Indian culture and religions (as described below), we should expect that these trends in the global flow of money and missionary methods that favour the greater pentecostalization of India also favour an increase in HinduChristian conflict and violence.

\section{Internal Factors in the Disproportionate Targeting of Pentecostals}

With this exposition on Hinduvta in mind, we can turn directly to the internal ${ }^{8}$ Pentecostal factors relevant to the disproportionate targeting

8. Though it makes sense to call these factors "internal", it should also become clear to the reader that a number of these factors become relevant to the disproportionate targeting of Pentecostals in anti-Christian violence only in relation to the external Hindu and non-Pentecostal Christian groups that find them objectionable. 
of India's Pentecostals in anti-Christian violence. A variety of major and minor factors can be adduced, but for the sake of simplicity, I will group them under three broad headings related to certain widely common (if not fully universal) characteristics of Indian Pentecostalism, the first of them adumbrated at the end of the previous section:

1 evangelical assertion and enthusiasm;

2 the greater presence and participation of marginalized and vulnerable peoples; and

3 the Pentecostal rhetoric of "rupture" and promotion of portable religious identities. ${ }^{9}$

\section{Evangelical Assertion and Enthusiasm}

While certain self-identified non-Pentecostal Evangelicals ${ }^{10}$ may be, on average, as active in evangelism as Pentecostals, many of my interlocutors in India, whether Christian or non-Christian, considered Pentecostals more "enthusiastic" and "zealous" in their evangelism, and also more likely to cause offence. Assessments varied on whether such characteristics were positive or negative, of course, but the opinion of a Protestant, charismatic mission organization leader was typical: "The Pentecostals are on the offensive", he said, "The mainlines are all status quoists." The evangelical enthusiasm of Pentecostals makes them more "visible", as another Indian Pentecostal interviewee put it, and therefore more likely to provoke and suffer the consequences of a reaction. This appears to be somewhat of a pan-Asian, or even a global phenomenon (Ma, 2005: 76).

Closely related to this point is that many of those I interviewed - again, both Christian and non-Christian - perceived Pentecostal evangelism to be more aggressive, assertive and critical of other faiths than that of other Christians; more so, even, than the self-identified non-Pentecostal Evangelicals whose mission activity might rival or even surpass that of Pentecostals. The critical idiom in which many Pentecostal evangelists are willing to operate, their inclination towards condemning the "idols" of Hinduism (or even rival Christian denominations) certainly sets them apart, and is an important aspect of the Pentecostal "rhetoric of rupture" I discuss more fully below. As Arun Jones writes, "A certain brand of Pentecostal preachers in India seem to relish the opportunity publicly

9. The research presented in this section first appeared in Bauman (2015), and appears here (in altered form) with permission of Oxford University Press.

10. That is, Evangelicals not associated with the larger, Euro-American Evangelical denominations that in India at least are less inclined towards evangelism. 
to condemn other religions - and perhaps at times even other Christian groups - and thus gain some notoriety for themselves" (Jones, 2009: 508).

As if to demonstrate Jones's point, the Indian leader of a large, international Pentecostal mission organization that operates in India repeatedly referred, in conversations with me, to the Indian God, Vishnu, as "the personification of the devil".

"Do you say that publicly in India?" I asked, with some incredulity, given the status and education of this contemporary mission leader (and the fact that many I had met in positions like his had come to temper such language).

"Yes, I do", he replied, unabashed, even cocksure.

It should be noted, of course, that the threat of anti-Christian violence has encouraged Indian Christians, and even Pentecostals, as Julia Kuhlin $(2015: 42,46)$ demonstrates, to be somewhat more subdued in their criticism of Hinduism, and somewhat less confrontational in their evangelical approaches. But this movement among Pentecostals appears to me far less advanced than it is in other parts of the world where Christians are under pressure (e.g. Sri Lanka, where I have been surprised by Pentecostals' comparatively more irenic characterizations of nonChristians and more widespread ecumenical and interfaith work).

While many mainstream Christians may criticize Pentecostals' confrontational style, Pentecostals themselves often consider their confidently critical disposition not only defensible, but a biblically-mandated forthrightness effective at exposing the error of non-Christian beliefs and snapping apathetic believers out of their religious complacency. Many other Pentecostals consider such confrontations the only appropriate way to engage with the "spiritual powers of darkness" that rule the bodies and minds of non-Christians. Nevertheless, it is important not to overgeneralize. Some Pentecostals condemn these confrontational approaches, and worry that they are unnecessarily provocative. As one interviewee put it, "Sometimes when we are overzealous and we take some unnecessary steps in preaching the gospel, then we can invite trouble for ourselves."

Another reason for Pentecostals' disproportionate targeting in acts of anti-Christian violence is their success. According to the most reliable indicators, Pentecostalism is growing at a rate higher than that of any other form of Christianity in India. ${ }^{11}$ It is, moreover, my impression

11. The growth is particularly pronounced, Former Evangelical Fellowship of India President Richard Howell maintains, among neo-Pentecostal churches led by 
(though the data are somewhat anecdotal) that Pentecostals are more active than others in un-Christianized areas, provoking conversions and establishing churches in territories where Christianity is unknown. Indian Christian mission workers are nearly unanimous in their opinion that evangelistic work is far more likely to provoke a vehement or even violent backlash in such areas than in areas where Christianity has already been established. It is also worth noting that Pentecostals have been quite successful at gaining converts from mainstream Protestant, Catholic and Orthodox communities, and that many Christians in those communities who have not formally converted attend Pentecostal worship services on the side, or even surreptitiously (i.e. against the wishes of their regular pastors and priests). This fact causes many mainstream Christians to resent and in some cases marginalize their Pentecostal coreligionists. This marginalization within the Christian community exacerbates the vulnerability of Pentecostals to attack.

\section{Participation of Marginalized/Vulnerable Peoples}

A second category of internal Pentecostal factors in the targeting of Pentecostal Christians is their individual and collective marginalization. Among the most important factors that fall within this category are these:

- Pentecostals' sectarian nature (which diminishes the possibility that they will be allied with broad and protective denominational networks); and

- the comparatively somewhat greater participation and leadership, in some Pentecostal contexts, of women and lower-caste/ tribal Indians.

The centrality, among Pentecostals, of living a life in obedience to one's conscience, guided by the Holy Spirit - a guidance to which all believers theoretically have direct access - contributes to a spiritual individuality that encourages fissiparous congregational life and presents an obstacle to the creation of broad, denominational alliances, particularly among neo-Pentecostal and independent, pentecostalized Evangelical churches (Csordas, 1997: 133; Robbins, 2010: 162). Not only do socially marginalized Christians make for more appealing targets (since those that might

first-generation converts. Interestingly, while the growth of Christianity in India is low for Asian countries (2.75\%, i.e. not even in the top ten), the growth of "Renewalism" in South Asia (which includes Pakistan, Bangladesh, etc.) is higher than anywhere else in the world (about 5.21\%). See Johnson and Ross (2009: 35, 43, 101). 
target them can reasonably worry less about negative repercussions), but when members of such congregations are threatened, harassed, attacked, or hauled into court, they are unable to call upon the institutional support networks available to members of mainstream Protestant, Catholic and Orthodox Christians that might help them respond effectively or even avoid such situations altogether. (And this, as I mentioned earlier, is probably one factor in the general lack of targeting of Roman Catholic charismatics.)

The effects of the sectarian nature of Pentecostal polity are further exacerbated by the fact that India's mainstream Protestant, Catholic and Orthodox Christians distance themselves from Pentecostal Christians, particularly during periods of violence. Many mainstream Christians believe that Pentecostals are "undisciplined" and unnecessarily adversarial in their evangelism, that non-Christians can't be blamed for reacting harshly or even violently to that adversarial evangelism, and that, therefore, Pentecostals actually deserve to be attacked, or at least shouldn't complain when they are (Jones, 2009: 507-8). The mainstream Christian marginalization of Pentecostals is for this reason, at least in part, a pragmatic one, part of a strategy to avoid their own victimization.

But there is another, more substantive, reason as well. The term, "undisciplined", appears in quotation marks in the previous paragraph because it was a term my mainstream Indian Christian interviewees often applied to Pentecostals. The view of Pentecostals as "undisciplined" is one shared not only by non-Christians, but also by many more "respectable" mainstream Protestant, Catholic and Orthodox Christians. To some extent, these prejudices about Pentecostal Christians may emerge from universal religious tensions between liturgical and authorized forms of religion, on the one hand, and free or ecstatic forms of religion, on the other. But the antipathy also reflects issues unique to India.

One of the most important of these is caste. Among the prevailing popular theories of anti-Christian violence in India, one of the most common is that it is not actually anti-Christian violence, but is, rather, anti-dalit (that is, anti-lower-caste) violence, carried out by local elites against their lower-caste neighbours under the pretence of responding to Christian provocation (because responding to Christian provocation is a more socially acceptable justification for violence than mere caste prejudice, and does not threaten the unity of "Hinduism" as constructed by Hindu nationalists to include all Hindus of all castes, despite historical prejudices against the dalits). At the very least, it is certainly true that the intersecting religious and caste identities of lower-caste Christians make 
them more vulnerable to anti-Christian violence than their upper-caste counterparts.

It is perhaps not surprising, then, that many identify the generally greater participation of lower-caste Christians in Pentecostal church leadership as a significant factor in their disproportionate targeting. After the 1970s, as the neo-Pentecostal movement gained momentum, and as foreign missionaries came to be replaced by native missionaries in greater and greater numbers, lower-caste Christians became more numerous and more visible in the leadership of Pentecostal churches, particularly in North India (Thomas, 2008: 319-23). This era also coincides with the rise of human and dalit rights movements in India (not all of which were Christian in leadership). Inspired by such movements, perhaps, some dalit Christians established their own, independent, churches, for the very purpose of extricating themselves from what they perceived to be the higher-caste domination of most mainstream Protestant, Catholic and Orthodox churches. As a result, and relative to mainstream Indian Christianity, lower-caste Indians are, in general, far more active in the leadership of Pentecostal churches. The fact that this is a generality must be acknowledged and emphasized. There are regional differences, in this regard, and parts of India where Pentecostal leadership is drawn more evenly from diverse social locations (Hedlund, 2005: 221).

Aside from the more formal positions of leadership, it is also the case (again, in general), that lower-caste lay Christians participate more actively in the religious life of Pentecostal churches than they do (or are permitted to do) in mainstream Christian contexts. The prominence of charismatic gifts within the Pentecostal environment allows for this, since participation is not centralized in the clerical hierarchy, as it is in mainstream Christian contexts, but is instead diffused widely among evangelists, prophets, healers and those who speak in or translate tongues. "The strength of the Dalit Pentecostal Churches", V. V. Thomas writes, "is that they allow full participation of almost all the members" (Thomas, 2008: 376). Or, as Fr. Selvaraj Arulnathan of the Indian Social Institute put it in conversation with me, in the mainstream churches the "dalits have no role", but in the Pentecostal churches, "Instantly they can raise their voice, instantly they can give their testimony, become pastors, etc."

The mainstream Protestant, Catholic and Orthodox churches in India, as one Charismatic mission leader told me, "have taken their stand with the upper-caste elite government ... They have name and fame and they have the largest property. They have a lot to lose ... They don't want to disturb the system." Desiring to preserve their status and reputation, 
they are disinclined, then, to welcome or associate themselves with dalit Christian communities, unlike Pentecostal churches, many of which are focused more on growth than status, and will, as Arun Jones writes, "welcome whoever they can get" (Jones, 2009: 509).

The prejudices of middle- and upper-caste Christians regarding lowercaste Christians are shared by upper-caste Hindus. I have argued previously (Bauman, 2013) that the anti-Christian riots in Kandhamal appear to have been at least partly engineered by upper-caste Hindu merchants and land-owners, in league with the lower-caste and tribal communities that most directly competed with Christians there, as a response to the Christians' increasing economic competitiveness and political assertion. It is likely that something similar is at work, if on a smaller scale, in the context of the everyday incidents of anti-Christian violence. Christianity in India often awakens among lower-caste converts a new sense of selfworth and dignity, while providing greater educational, vocational and economic opportunities (like agricultural cooperatives). The effects are marginal, but discernible by those who live in close proximity to Christians because they often help turn formerly exploited lower-caste and tribal Christian communities into full-fledged competitors in the local economy, a transformation that irritates and provokes those in the local community who now must compete with them, sometimes even to the point of a violent response. While this is true in general for India's Christians, the effects may be positively compounded in Pentecostal contexts, because of the strong emphasis there on hard work and clean living.

The fact that women are somewhat more active and visible in the activity of at least some Pentecostal churches is another factor in their marginalization. Though the prominence of Pentecostal women in India may lag behind that in Pentecostal contexts elsewhere, they often participate unreservedly and exuberantly in worship. Women constitute the majority of religious participants worldwide, of course, but there may be reasons why women are particularly drawn to Pentecostalism, such as the very fact that they can participate more actively in the life of the church, and the fact that Pentecostal spiritual healers (including many women) claim and are widely perceived to be adept at addressing the underlying spiritual causes of problems of particular concern to women (e.g. domestic abuse, intemperance and its resultant dissipation, infertility, etc.). Whatever the causes, the prominent participation of women in Pentecostalism's ecstatic worship is itself considered inappropriate, and a mark of low social status by many higher-caste and higher-status 
non-Christians and Christians. But in addition, and perhaps as a consequence of their greater participation in the life of the church, Pentecostal women are often accused by their neighbours of adopting a more (and inappropriately) confident way of being in the world and relating to others (and especially to other men). In more traditional Indian contexts, where the presence of secluded and demure women is a mark of a community's higher-caste status (Mandelbaum, 1988), Pentecostal women's more confident way of being in the world represents yet another reason for their marginalization.

There are many reasons, then, for the marginalization of India's Pentecostal Christians. But what is clear is that to the extent that Pentecostals are perceived by their neighbours (rightly so, in many cases) to be a low-caste community, they suffer the consequences of anti-Christian bias compounded by anti-dalit bias. This makes them a more appealing target of violence. And when they do suffer attack, their marginalization from higher-status, larger and more powerful Christian communities makes it harder for them to effectively seek redress.

\section{The Rhetoric of "Rupture" and the Promotion of a Portable Faith}

In their survey and analysis of neo-Pentecostal Christians in India, Paul Parathazham's survey group included, as a defining feature of Pentecostalism, "an antagonistic attitude towards the world" (Parathazham, 1996: 81). Since most attempts to define Pentecostalism always a risky venture - have focused on the centrality of the Holy Spirit and its gifts, the inclusion of this defining vector struck me, at first, as rather odd. But anyone who has studied Indian Pentecostalism already knows what I did not, which is how common and distinctive a feature of Pentecostalism "antagonism" really is. To use Joel Robbins's terminology, Pentecostals worldwide promote radical "rupture" with what came before, and undergo radical personal transformations effected by "a series of ruptures with the ways in which they have lived up to the time of their conversion" (Robbins, 2010: 159; see also Robbins, 2007).

Providing an appreciative critique of Robbins's work, Birgit Meyer has helpfully cautioned us not to forget that "rupture necessarily implies some kind of discursive continuity, if only because 'being against' always entails some degree of 'being with"' (Meyer, 2010: 121). In my view, these two positions can be reconciled if we do not take Pentecostals fully at their word, that is, if we bear in mind the "rupture" promoted by Pentecostals is, first and foremost, rhetorical. Because it is frequently enacted in rituals (like exorcism and baptism), rhetorical rupture can certainly have real 
effects (Robbins, 2010: 161). But the mere claim to have achieved full rupture with what came before certainly does not preclude the possibility of unconscious or unacknowledged continuities, syncretisms and hybridities.

The individual "rupture" that Pentecostals promote also necessarily entails communal rupture with what are deemed "non-Christian" elements of the believer's past. As Birgit Meyer writes, "Pentecostals tend to mobilize a diabolizing stance toward indigenous gods, which are recast as demons operating under the aegis of Satan" (Meyer, 2010: 121). Pentecostals therefore often construct a religious culture "against culture", to borrow Dombrowski's phrase (Robbins, 2010: 121). In the view of many I interviewed, the diabolizing stance of Pentecostals was the primary reason for their disproportionate targeting.

The Pentecostal response to such targeting may exacerbate the issue. Many religions advocate some degree of isolation from or opposition to "the world", the past, or aspects of contemporary culture. "The existence of cultural tension", argues Robbins, is therefore "not in and of itself what makes Pentecostal culture unique". Instead, what "distinguishes Pentecostal culture from others is that it does little to reduce such tensions but rather encourages and feeds off them" (Robbins, 2010: 161). Cultural friction, or opposition, then, animates many Pentecostals, and serves, to the extent that it recalls what Jesus and his disciples sometimes experienced, to confirm the credibility of their faith. The peculiarity of Pentecostals in this regard was particularly evident among Pentecostals engaged in evangelism, who regularly evinced a penchant for provoking non-Christians, even to the point of violence. Independently of one another, at least three Pentecostal or pentecostalized evangelists told me that any evangelist worthy of the name should be going out and "getting some slaps" (cf. Kuhlin, 2015: 50). Shocking as it may be, the statement follows a clear logical pattern. After all, there is no more sure sign of having achieved rupture with one's culture than to be beaten up by one's neighbours. Only the martyr is pure.

Pentecostals' rhetoric of rupture, then, is surely partly responsible for the claim that Pentecostals, more so even than many other Christians, are denationalized. But this rhetoric is particularly provocative when it is combined, as is sometimes (but certainly not always) the case among Pentecostals, with a predilection for the English language, and for contemporary Euro-American worship and sartorial styles. When it is, then the critics of Pentecostalism begin to suspect that Pentecostal religious 
culture takes its cues not from the Bible, as Pentecostals would contend, but from Euro-American Christianity.

The signs of influence from European and American contemporary Christian worship trends are everywhere in at least some Indian Pentecostal churches, though not in all, as Julia Kuhlin has helpfully pointed out (Kuhlin, 2014). In such Pentecostal contexts, which I found to be more prevalent in North India than in South India, ${ }^{12}$ congregants wear jeans and sing songs with English lyrics written in California or Australia, and led by worship teams playing keyboards, guitars and drums, and affecting the vocal intonations and pious idiom of their Vineyard and Hillsong counterparts. I even once detected a southern American twang in an Indian Pentecostal worship teams' rendition of "The Old Rugged Cross", ${ }^{13}$ and in Pentecostal circles, it seemed impossible to go more than a few hours without hearing a mobile phone ring to the tune of "Awesome God" (a contemporary American Christian worship song). ${ }^{14}$

Though non-Christians may for a variety of reasons find Christian worship services unappealing, some seem to take special offence when they hear the use of what they perceive to be non-Indian instruments, scales and song styles, and the offence they take at what they perceive to be the "denationalized" religious expression of Pentecostals is exacerbated by its volume and zest. In fact, it is not merely non-Christians that perceive it this way. As one Christian (but non-Pentecostal) mission leader in rural Andhra Pradesh grumbled, "The sound and the screaming [is] like fuel on fire".

A common characteristic of Pentecostal worship worldwide is that it is loud, and often amplified by magnificent sound systems. (The joke in India, and perhaps elsewhere, is that Pentecostal church planters purchase powerful sound systems first, and worry about where to use them only afterwards.) As Birgit Meyer has put it, in Pentecostal worship:

12. This, however, should be considered anecdotal evidence only, since I know of no systematic regional comparison of India's Pentecostals in this regard.

13. "The Old Rugged Cross" is an early twentieth-century hymn written by American evangelist George Bennard.

14. "Awesome God" is a popular contemporary Christian song written by Rich Mullins in the 1980s. The lyrics of the chorus are, "Our God is an awesome God / He reigns from heaven above / With wisdom pow'r and love / Our God is an awesome God." For a critical comment on "Americanization" among Indian Christians as another form of "cultural imperialism", see Frykenberg (2004: 129). 
Loudness - to such an extent that participants' bodies vibrate from excess of sound - and also pastors' use of microphones in rhythmic sayings induce a certain trancelike atmosphere that conveys a sense of an extraordinary encounter with the divine force that is experienced to be present and that can be reached by opening up and stretching one's arms. (Meyer, 2010: 124)

The offence taken by unsympathetic observers at what they construct as an alien musical style (in Pentecostal contexts where the use of contemporary Christian music originating in Europe, America and Australia is the norm) is therefore compounded by what in many cases is its high volume. That said, religious competition for sound wave airspace is nothing new in India, and certainly not particularly Pentecostal. The "alien" nature of Pentecostal music is therefore the primary factor, and the volume merely an exacerbating one.

This issue of volume is particularly salient when Pentecostals meet in house churches, in residential neighbourhoods where their worship intrudes upon the lives of others more than it would if it were cordoned off in the larger church compounds typical of mainstream Protestant, Catholic and Orthodox churches. House churches are not merely a concession for impecunious Pentecostals, but are rather, for some at least, a consciously chosen strategy. But the existence or establishment of house churches is a frequent flash point in Hindu-Christian relations, and in the absence of zoning laws, Hindus sometimes resort to mob violence, threats of violence and/or legal harassment to harry house churches and encourage them to relocate.

A story told to me by a North Indian Pentecostal pastor, who had himself been a victim of anti-Christian violence several times, illustrates many of the points advanced in this section. (And since I first related the story in my book, I will simply quote from it here.):

A church he had established was renting a private hall on Sunday mornings. The hall was in a residential area, next to the home of a retired army Colonel who complained about the noise. The Pastor agreed to turn down the volume. Nevertheless, one Sunday, the Colonel sent for the police and asked them to do something about the noise. The police arrived during worship. Youth from the church told the pastor that the police were waiting for him outside. He said to the police, "I am with the Lord; I'll not come out until after the service." The police didn't want to disturb the service, so they told him to come to the station afterwards. He did, and found that there was a report lodged against him there for disturbing the peace. He made excuses, saying that they were only temporarily worshipping in that hall, and that they were looking for a permanent place. He assured them that they would shut the windows, and not use microphones, and 
reminded them that their worship happened only once a week, and the singing lasted only half an hour. The police let the pastor go, which did nothing to mollify the Colonel, who believed the Pentecostal worship was still too loud, even without amplification. So he told the pastor, "Now you will see what I can do." The next Sunday, the Colonel erected his own, massive sound system. As the Pentecostals began to sing, he started blasting Bollywood film songs in their general direction. But less than a half a minute passed before the electricity in the entire neighborhood went off. The congregation kept singing; the film songs fell silent. The Pentecostals, of course, interpreted it as a miracle. (Bauman, 2015: 89)

Let me conclude this section with a final note on the relationship of Indian Pentecostalism to prevailing Indian cultural norms. As Birgit Meyer has suggested, taking inspiration from the work of David Martin, "Pentecostalism launches an alternative understanding of the person as a mobile self with a 'portable identity' and concomitant 'portable practice' and 'transportable message,' all being conducive to spatial and social mobility" (Meyer, 2010: 121; see also Martin, 1990: 24). This "portable identity" and "social mobility" run counter to prevailing (if contested) Indian notions of identity that construct and subsume the individual within identities of place, community and caste, just as the universalizing, "transportable message" of Pentecostalism runs counter to prevailing (though not universally consistent) Indian religious conceptions of the divine as rooted (but also differently manifest) in particular geographical places, villages, rivers, trees, shrines, etc. This is nowhere more evident than in conversion to Pentecostalism, or at least in the conversion of individuals, which implies an understanding of religious identity that is malleable and constructed at the individual's discretion. The fact that it does so, and that it arguably does so more than most other forms of Indian Christianity, may constitute yet another reason for the perception, among its Hindu and Christian critics, that India's Pentecostal Christians are particularly denationalized, and probably, therefore, yet another reason for their disproportionate targeting in anti-Christian violence.

\section{Conclusion}

Among the reasons why Pentecostals are disproportionately targeted are some that are rather obvious. We must begin, of course, with the fact of Hindu nationalism, fuelled by the ideology of Hindutva, and concerned about the social and political ramifications of the growth of Christianity (or willing to exploit such concerns in others for the sake of political gain). In the context of such a Hindu nationalism that constructs and 
perceives Christian presence and growth as a threat to both Hinduism and its own political power, the universalizing and expansionistic nature of Christianity in general, and the assertive evangelism of Pentecostalism in particular, is clearly provocative. It is important to underscore, however, that apart from those rare cases in which Christians implicitly or explicitly offer inducements to conversion in states that have "religious freedom" laws prohibiting the practice, neither the expansionistic nature of Christianity nor the assertive evangelism of Christians is in any way against Indian law. Meanwhile, resorting to violence in response to "provocative" but legal social actions is most definitely against the law. It must be counted as among the most astonishing and concerning achievements of Hindutva organizations in India, then, that they have managed to portray Christianity as such a threat to the Indian nation that many of their partisans consider anti-social violence less of a threat to the stability of the nation than the critical religious utterings of a street preacher. This achievement depends on the modern and colonial emergence of "religion" as something clearly differentiable from "culture", and "religions" as discrete, non-overlapping and competing entities, the locus of communal identity and political power. But it also depends on the conscious construction of a primordially and homogeneously "Hindu" nation that effaces a more complex history in service of the preservation of an imagined "Hindu" unity. Only in the context of such a construction can the growth of Christianity by any method be construed as a threat to the nation. And only in the context of such a construal could extra-legal violence be portrayed as a "natural" response to aggressive evangelism.

Similarly, that Pentecostals' rhetoric of "rupture", should leave them more vulnerable to charges of denationalism, which are used by their opponents to authorize and justify acts of violence against them, depends again upon the conscious construction of an ahistorical, simplified, homogenized notion of "Indian" culture that equates it with one particular subset of (primarily high-caste) Hindu mores. It also presumes that this rhetoric accurately reflects the reality. The rhetoric of "rupture" may be more pronounced among Pentecostals, in general, than among other Indian Christians, and to some extent it may reflect a greater degree of cultural critique than one finds elsewhere. Nevertheless, there are countervailing trends, the most important of which is spiritual healing, in which Pentecostals enthusiastically engage, and which draws directly on a popular religious idiom and milieu that they share with adherents of all religions in India (Bauman, 2015: ch. 4). It is telling that Hindu nationalist claims that Christianity is a denationalizing religion fall silent in the 
context of discussions of faith healing. If nationalists critique Christian faith healing at all, it is as "quackery", not as something anti-Indian. Nevertheless, the comparatively more developed Pentecostal rhetoric of rupture leaves them more vulnerable to nationalists' critique, and remains another reason why they are disproportionately provocative, and disproportionately targeted.

The third broad internal Pentecostal factor I identified, the greater presence and participation, in Indian Pentecostalism, of marginalized peoples (especially women and dalits) functions to disadvantage Pentecostals in two ways. First, to the extent that this participation is perceived as a form of lower-caste assertion, it risks provoking a backlash among local elites and others committed to preserving the social status quo. Second, to the extent that this participation contributes to the perception that Pentecostalism is a low-status religion for low-status people, Pentecostals come to be marginalized by higher-caste and higher-status Hindus, and by higher-caste and higher-status Christians. (This marginalization is furthered and encouraged by Pentecostals' tendency to demonize both groups.) Because of this, Pentecostals are both more vulnerable to attack and less capable of mounting an effective response.

With all three of the internal Pentecostal factors described above, it must be emphasized that we are dealing in generalities. Not all Pentecostals are particularly assertive in their evangelism. Not all Pentecostals deploy a rhetoric of rupture. And certainly women and dalits are not prominent in the leadership and life of all Pentecostal communities. And this is why it is important, when reading the arguments above, to attend carefully to words like "somewhat", "generally" and "comparatively". The situation here is one of relative and sometimes minor differences, which vary from context to context, and may disappear altogether in some, but which in the aggregate, help account for the disproportionate targeting of Indian Pentecostals in anti-Christian violence in the context of a Hindu nationalism that frames Christianity (and particularly Christian growth) as a threat to the nation.

That Pentecostal Christians are disproportionately targeted is clear enough, but whether that targeting is conscious or not is another question. When I posed this very question to a dalit rights activist, he responded metaphorically: "If a cockroach lands on your shoulder, what will you do?" His point was clear: The targeting of Pentecostals in antiChristian violence was the cumulative result of instinctual (meaning: unconscious) reactions to particular provocations, reactions which in the aggregate disproportionately affect Pentecostals because they are 
more regularly the source of the provocations, and also because, like the cockroach that lands on your shoulder, Pentecostals are more accessible and vulnerable victims.

That vulnerability is related, as I have argued above, to the marginalization of Pentecostals by other Christians both because of Pentecostals' disposition with regard to these Christians, and because of factors beyond their control (e.g. caste prejudice, prejudice against ecstatic religion, etc.). Those analysing anti-Christian violence in India have tended to focus on interreligious issues, that is, on the reasons for HinduChristian tension and conflict. These are important, as acknowledged from the outset of this article. However, as I have demonstrated here, we cannot understand the issue of anti-Christian violence fully without paying heed to the intra-Christian dynamics as well. India's mainstream Protestant, Catholic and Orthodox Christians have distanced themselves from Pentecostals for at least four reasons. First, there are the common prejudices that more established, "traditional", hierarchical and liturgical religious communities have for those whose worship is more free, unstructured and ecstatic. Second, though it is not universally true, relative to Pentecostal Christians, India's mainstream Christians tend, in general, to enjoy a higher social status, a higher social status they desire to maintain, which requires, inter alia, that they keep their distance from lower status communities. Third, India's mainstream Christians, who are generally less inclined towards evangelism, have assimilated to some extent (or perhaps even facilitated) the Hindu nationalist construction of evangelism as something uncouth and threatening, and for this reason fault their Pentecostal counterparts for being aggressively evangelistic, hoping, by dissociating themselves from their evangelism, to avoid the backlash that they not only expect, but in many cases view as natural, even merited. Finally, and related to the third point, India's mainstream Christians resent Pentecostals (and other more evangelistic Christians) for the fact that they have lured large numbers of mainstream Christians into their fold as formal members and informal participants in worship and healing services.

For all of these reasons, India's mainstream Christians tend to disparage their Pentecostal coreligionists, deploying stereotypes and language that Hindu nationalist critics of Christianity borrow and amplify. And this, of course, is a global pattern. As André Droogers has helpfully pointed out, mainstream Christians "have been the most important outsider source of essentialist and normative images regarding Pentecostal believers", labelling them "fanatic, schismatic, heretic, and 
sectarian" (Droogers, 2010: 38). To this list, drawing from my interviews with Indian Christians, we could add many more: "fundamentalist", "hysterical", "emotional", "uneducated", "cultish", "intolerant". An Indian Catholic nun quoted by journalist Shafi Rahman demonstrates the way these claims are often made indirectly, even politely, through insinuation: "These [independent Pentecostal] preachers are not trained in theology", she said. "They often play with the sentiments of people and lure them with incentives and create communal tension. We are forced to take the blame for their wayward preaching methods" (Rahman, 2011: 38). After quoting the nun, Rahman perceptively provides a concise and appropriate concluding summary for this analysis of the disproportionate targeting of Pentecostals in India's anti-Christian violence: "both mainstream churches and Hindutva parties", he writes, "love to hate" these independent pastors (Rahman, 2011: 37).

\section{Acknowledgements}

I am indebted to the Center for Religion and Civic Culture at the University of Southern California, the Templeton Foundation, the American Academy of Religion, and Butler University, for funding that supported this research. I am also grateful to GloPent for the opportunity to present the research as a keynote address at their ninth conference in Uppsala, Sweden (2016). Thanks in particular to Kajsa Ahlstrand, JanÅke Alvarsson and Julia Kuhlin for their warm hospitality. Thanks as well to Kerry San Chirico, Arun Jones and Michael Bergunder, who read and provided helpful feedback on an earlier draft (the latter as respondent at the conference itself). While I am no doubt incapable of rising to the full challenge of their critiques, the paper is far stronger because of them.

\section{References}

Anderson, A. and E. Tang (eds). 2005. Asian and Pentecostal: The Charismatic Face of Christianity in Asia. Costa Mesa, CA: Regnum.

-, M. Bergunder, A. Droogers and C. van der Laan (eds). 2010. Studying Global Pentecostalism: Theories and Methods. Berkeley, CA: University of California Press.

Barrett, D. B., G. T. Kurian and T. M. Johnson. 2001. World Christian Encyclopedia: A Comparative Survey of Churches and Religions in the Modern World. Oxford: Oxford University Press.

Bauman, C. 2013. 'Hindu-Christian Conflict in India: Globalization, Conversion, and the Coterminal Castes and Tribes". Journal of Asian Studies 72: 633-53. https://doi.org/10.1017/S0021911813000569

- 2015. Pentecostals, Proselytization, and Anti-Christian Violence in Contemporary India. Oxford: Oxford University Press. 
— and T. Leech. 2011. "Political Competition, Relative Deprivation, and Perceived Threat: A Research Note on anti-Christian Violence in India". Ethnic and Racial Studies 35: 2195-216.

Bayly, S. 1989. Saints, Goddesses and Kings: Muslims and Christians in South Indian Society 1700-1900. Cambridge: Cambridge University Press.

Bergunder, M. 2008. The South Indian Pentecostal Movement in the Twentieth Century. Grand Rapids, MI: Eerdmans Publishers.

Csordas, T. J. 1997. Language, Charisma, and Creativity: The Ritual Life of a Religious Movement. Berkeley, CA: University of California Press.

Droogers, A. 2010. "Essentialist and Normative Approaches". In Anderson et al. 2010: 30-50.

Freitag, S. B. 1989. Collective Action and Community: Public Arenas and the Emergence of Communalism in North India. Berkeley, CA: University of California Press.

Frykenberg, R. 2004. 'Gospel, Globalization, and Hindutva: The Politics of 'Conversion' in India”. In D. M. Lewis (ed.), Christianity Reborn: The Global Expansion of Evangelicalism in the Twentieth Century. Grand Rapids, MI: William B. Eerdmans: $108-32$.

Harper, S. B. 2000. In the Shadow of the Mahatma: Bishop V. S. Azariah and the Travails of Christianity in British India. Grand Rapids, MI: William B. Eerdmans.

Hedlund, R. 2005. "Indigenous Pentecostalism in India". In Anderson and Tang 2005: 174-97.

Jaffrelot, C. 1996. The Hindu Nationalist Movement in India. New York: Columbia University Press.

Johnson, T. and K. Ross. 2009. Atlas of Global Christianity 1910-2010. Edinburgh: Edinburgh University Press.

Jones, A. 2009. "Faces of Pentecostalism in North India Today". Society 46: 504-9. https://doi.org/10.1007/s12115-009-9264-z

Kidambi, P. 2007. The Making of an Indian Metropolis: Colonial Governance and Public Culture in Bombay, 1890-1920 (Ashgate: Hampshire).

Kim, S. C. H. 2003. In Search of Identity: Debates on Religious Conversion in India. Oxford: Oxford University Press.

Kuhlin, J. 2014. "Review of Chad Bauman, Pentecostals, Proselytization and Anti-Christian Violence in Contemporary India". Swedish Missiological Themes 102: 307-10.

- 2015. "Hindu-Christian Relations in the Everyday Life of North Indian Pentecostals". Journal of Hindu-Christian Studies 28: 40-54.

Ma, W. 2005. "Asian (Classical) Pentecostal Theology in Context". In Anderson and Tang 2005: 46-72.

Mandelbaum, D. G. 1988. Women's Seclusion and Men's Honor: Sex Roles in North India, Bangladesh, and Pakistan. Tucson, AZ: University of Arizona Press.

Martin, D. 1990. Tongues of Fire: The Explosion of Protestantism in Latin America. Oxford: Blackwell.

Meyer, B. 2010. “Pentecostalism and Globalization”. In Anderson et al. 2010: 113-30.

Parathazham, P. 1996. "Neo-Pentecostalism in India: Preliminary Report of a National Survey". Word and Worship 29: 81-101.

Rahman, S. 2011. "Freelancers of God". India Today International (30 April): 36-39.

Robbins, J. 2007. "Continuity Thinking and the Problem of Christian Culture". Current Anthropology 48: 5-38. https://doi.org/10.1086/508690

- 2010. "Anthropology of Religion". In Anderson et al. 2010: 156-78.

Sarkar, S. 1999. "Conversion and Politics of Hindu Right". Economic and Political Weekly (26 June): 1691-700. 
Savarkar, V. D. 1928. Hindutva: Who is a Hindu? Bombay: Veer Savarkar Prakashan.

Subramanian, A. 2009. Shorelines: Space and Rights in South India. Stanford, CA: Stanford University Press. https://doi.org/10.11126/stanford/9780804761468.001.0001

Thomas, V. V. 2008. Dalit Pentecostalism: Spirituality of the Empowered Poor. Bangalore: Asian Trading Corporation.

Zavos, J. 2001. "Conversion and the Assertive Margins". South Asia: Journal of South Asian Studies 24: 73-89. https://doi.org/10.1080/00856400108723451 